\title{
HUBUNGAN PERAN KEPEMIMPINAN TERHADAP KINERJA PEGAWAI PADA FAKULTAS MATEMATIKA DAN ILMU PENGETAHUAN ALAM (MIPA) UNIVERSITAS LAMPUNG
}

\author{
Raditte Husin $^{(1)}$, Muhammad Yusuf ${ }^{(2)}$ \\ Fakultas Ekonomi Universitas Sang Bumi Ruwa Jurai \\ raditte.husin@fe.saburai.ac.id,muh.yusuf19@gmail.com
}

\begin{abstract}
Abstrak. Peranan kepemimpinan ditinjau dari ilmu manajemen, diartikan sebagai kemampuan untuk mempengaruhi dan menggerakan orang lain, agar rela, mampu dan dapat mengikuti keinginannya untuk bekerja secara efisien dan efektif. Setiap organisasi selalu berusaha memacu kinerja pegawainya, sebagai indikator keberhasilan. Objek dalam penelitian ini adalah FMIPA Universitas Lampung. Tujuan penelitian adalah untuk mengetahui besarnya hubungan peran kepemimpinan terhadap kinerja pegawai pada Fakultas Matematika dan Ilmu Pengetahuan Alam (FMIPA) Universitas Lampung. Penelitian ini menggunakan metode analisis kualitatif dan kuantitatif, dengan regresi linier sederhana. Sampel penelitian ini menggunakan teknik sensus sebagian unsur populasi pada Fakultas MIPA Universitas Lampung berjumlah 35 orang. Hasil analisis regresi linier sederhana adalah $\mathrm{Y}=0,702+0,800 \mathrm{X}$ memiliki arti bahwa peranan kepemimpinan $(\mathrm{X})$ bersifat positif, jika dinaikan peranan kepemimpinan, maka nilai kinerja pegawai (Y) akan meningkat sebesar 0,800 . Hasil uji $\mathrm{t}$ student adalah $\mathrm{t}$ hitung 7,38 $>\mathrm{t}$ tabel 2,724 , maka dapat disimpulkan hipostesis penelitian "Ada pengaruh peranan kepemimpinan terhadap kinerja pegawai pada Fakultas Matematika dan Ilmu Pengetahuan Alam (MIPA) Universitas Lampung" diterima.
\end{abstract}

Kata kunci: Kinerja, Kepemimpinan, Pegawai, Peran.

\section{PENDAHULUAN}

Suatu organisasi atau korporasi, baik usaha berorientasi laba maupun jasa, mempunyai harapan keberhasilan mencapai tujuan, sangat ditentukan oleh adanya orang-orang baik dalam jumlah besar maupun kecil saling berkaitan dan ketergantungan, bekerja atas dasar pembagian kerja, peran dan wewenangnya. Dalam mengendalikan, mengarahkan dan mempengaruhi bawahannya sesuai dengan perintah kerja diperlukan kepemimpinan yang adil dan proposional. Betapun rendah kedudukan dan kecil jasanya harus dihargai, sehingga penerapan fungsi-fungsi manajemen di dalam organisasi dapat terlaksana secara efektif dan efisien.

Banyak organisasi menyadari betapa sulit dan kompleks, meningkatkan pencapaian target sesuai dengan rencana tujuan, memerlukan upaya yang serius. Keterpurukan ekonomi nasional yang berkepanjangan merupakan salah satu akibat dari rendahnya kualitas sumber daya manusia, sehingga produk atau jasa yang dihasilkan tidak mempunyai daya saing. Mengelola dan memberdayakan sumber daya manusia menjadi sesuatu yang sangat penting, seiring perkembangan ilmu pengetahuan dan teknologi, maka antara sesama korporasi akan menghadapi persaingan secara kualitas, kuantitas dan ketepatan waktu penyelesaian pekerjaan, guna untuk mencapai daya saing yang tinggi dan peningkatan profitabilitas.

Salah satu langkah pertama mengelola dan memberdayakan sumber daya manusia adalah organisasi harus merencanakan metode sistem penerimaan pegawai yang disesuaikan dengan kemampuan dan posisi penempatannya (kompetensi), berdasarkan 
ketentuan standar personalia. Langkah kedua adalah pemimpin perusahaan harus menyadari bahwa pegawai baru pada umumnya hanya mempunyai pengetahuan teoritis dari suatu sistem pendidikan, maka perlu dikembangkan kemampuan nyata untuk dapat mengerjakan tugasnya.

Demikian pula bagi pegawai lama perlu latihan, baik sebagai akibat kemajuan teknologi maupun tuntutan tugas baru menghadapi transfer atau promosi. Sedangkan untuk keseimbangan antara kepentingan, korporasi harus memberikan kompensasi didasarkan atas prinsip adil dan wajar, sehingga para pegawai dengan loyalitas dan mau bekerja sama melaksanakan tugas dan tanggung jawabnya.

Manajemen sumber daya manusia sudah merupakan persyaratan dalam dunia ketenaga kerjaan, kebutuhan pegawai di dalam bisnis akan menunjukkan bagaimana seharusnya organisasi mendapatkan, mengembangkan, menggunakan, mengevaluasi dan memeliharanya dalam jumlah (banyak) dan tipe (mutu) yang tepat. Sedangkan di dunia pendidikan, tujuannya lebih mengarah pada pembangunan pendidikan bermutu, membentuk sumber daya manusia yang handal, produktif, kreatif dan berprestasi.

Universitas Lampung merupakan salah satu Perguruan Tinggi Negeri di Propinsi Lampung, berlokasi Jl. Prof. Dr. Sumantri Brojonegoro No. 1 Bandar Lampung. Salah satu korporasi di dunia pendidikan berbentuk universitas. Berperan sebagai pusat perkembangan ilmu pengetahuan dasar, diantaranya adalah Fakultas MIPA yang mempunyai program studi Kimia, Biologi, Fisika, Matematika dan Ilmu Komputer. Status kepegawaian baik tenaga pendidik (dosen) maupun tenaga kependidikan (administrasi) pada Fakultas MIPA Universitas Lampung adalah Pegawai Negeri Sipil dan merupakan sumber daya manusia potensial, berperan aktif dalam mewujudkan tujuan pendidikan Nasional berada di bawah naungan Kementerian Riset, Teknologi dan Pendidikan Tinggi (KEMENRISTEK DAN DIKTI).

Kendala yang dihadapi oleh Fakultas MIPA Unila salah satunya adalah, sangat terbatasnya ketersediaan sarana dan prasarana bahan kimia laboratorium merupakan substansi pokok penyelenggaraan praktikum dan penelitian pada Program Studi Kimia, selain itu juga terdapat beberapa dosen sering tidak ada ditempat dikarenakan melanjutkan pendidikan $\mathrm{S}_{3}$ dan kegiatan penelitian di daerah lain, sehingga aktivitas perkuliahan relatif mengalami penurunan. Hal ini berdampak terhadap rendahnya kualitas mahasiswa/i yang masuk (sebagai input) dan tingkat kompetitif mahasiswa/i yang diterima dikarenakan kurangnya peminat mendaftar.

Melihat fenomena di atas, menunjukkan bahwa ada indikasi kurangnya peranan pimpinan dalam mengendalikan atau memanajemen seluruh aktivitas program studi pada Fakultas MIPA Unversitas Lampung, dalam rangka menciptakan ide dan gagasan-gagasan baru, inovatif pengembangan maupun mengantisipasi berbagai penyimpangan atau hambatan, sehingga dapat berdampak terhadap tingkat kinerja pegawai administrasi maupun pendidik (dosen) berkecendrungan menjadi menurun.

Menurut Alex S. Nitiseminto (2012) kepemimpinan adalah seni kemampuan mempengaruhi perilaku manusia dan kemampuan mengendalikan orang-orang dalam organisasi, agar supaya perilaku mereka sesuai dengan perilaku yang diinginkan oleh pimpinan. Menurut Luthans (2012) kinerja adalah menilai bagaimana seseorang telah bekerja dibandingkan dengan ketentuan target, merupakan perilaku nyata sebagai prestasi kerja yang dihasilkan sesuai dengan perannya dalam 
suatu organisasi. Menurut Dharma (2011) penilaian kinerja, dapat dilihat dari kemampuan pegawai menghasilkan mutu yang baik, kuantitas atau jumlah yang dihasilkan dalam kurun waktu tertentu dan ketepatan waktu penyelesaian pekerjaan sesuai atau tidaknya dengan rencana yang telah ditetapkan. Berdasarkan uraian tersebut, peneliti melakukan penelitian lebih lanjut dengan judul: "Hubungan Peran Kepemimpinan Terhadap Kinerja Pegawai Pada Fakultas Matematika dan Ilmu Pengetahuan Alam (MIPA) Universitas Lampung".

\section{KAJIAN TEORI}

\section{Manajemen Personalia}

Manajemen personalia adalah ilmu manajemen yang menitik beratkan perhatiannya kepada masalah admistrasi kepegawaian di dalam suatu organisasi. Sesungguhnya persoalan administrasi adalah persoalan manusia. Tidak ada kegiatan administrasi yang dapat berlangsung tanpa manusia, meskipun lengkapnya fasilitas, besarnya biaya tersedia, modernnya perlengkapan, dan majunya ilmu pengetahuan serta mutakhirnya teknologi. Menurut Sondang P. Siagian (2012) administrasi pada dasarnya adalah suatu proses pelaksanaan kegiatan tertentu, dilaksanakan oleh dua orang manusia atau lebih melibatkan diri dalam suatu usaha bersama untuk mencapai tujuan yang telah ditentukan sebelumnya.

Organisasi adalah wadah serta proses kerja sama sejumlah manusia yang terikat dalam hubungan formal dalam rangkaian hirarki untuk mencapai tujuan yang telah ditentukan. Pada umumnya manusia terlibat dalam proses administrasi biasanya memusatkan perhatiannya kepada pelaksanaan kegiatan-kegiatan yang harus dilaksanakan demi tercapainya tujuan dengan efektif dan efisien serta ekonomis.
Manusia merupakan unsur terpenting dari administrasi karena dari semua unsur yang lain, seperti ; tujuan, misi, tugas pokok, fungsi, organisasi dan peralatan hanya merupakan benda mati tanpa adanya manusia. Keterlibatan manusia dalam proses pelaksanaan kegiatan-kegiatan tertentu biasanya diwujudkan dalam suatu hubungan yang bersifat formal.

Manajemen personalia adalah bidang manajemen, khusus mempelajari hubungan dan peranan manusia dalam suatu organisasi. Organisasi dipandang sebagai suatu unit, mengubah berbagai input menjadi output yang diperlukan masyarakat dan sumber daya manusia merupakan unsur berperan di dalamnya. Berbagai upaya keahlian dan keterampilan selalu ditingkatkan untuk membentuk sumber daya manusia menjadi berkualitas, dimotivasi dan diberi penghargaan sebagai insani yang layak, disesuaikan dengan perekonomian masyarakatnya.

\section{Pengertian Kepemimpinan}

Seseorang dapat dikatakan pemimpin, jika, ia dapat mempengaruhi orang lain untuk mencapai sesuatu tujuan tertentu, meskipun tidak ada ikatan-ikatan yang formal dalam organisasi. Kepemimpinan akan timbul dimanapun, asalkan unsurunsur, seperti adanya orang yang dipengaruhi dan orang yang mempengaruhi serta orang yang mempengaruhi mengarahkan kepada tercapainya sesuatu tujuan. Ditinjau dari ilmu manajemen, kepemimpinan harus diartikan sebagai kemampuan untuk mempengaruhi dan menggerakan orang lain, agar rela, mampu dan dapat mengikuti keinginan untuk bekerja secara efisien dan efektif.

Menurut Alex S. Nitiseminto (2011) kepemimpinan adalah seni kemampuan mempengaruhi perilaku manusia dan kemampuan mengendalikan orang-orang dalam organisasi, agar supaya perilaku 
mereka sesuai dengan perilaku yang diinginkan oleh pimpinan organisasi. Sondang P. Siagian (2012) menyatakan kepemimpinan diartikan sebagai kemampuan untuk mempengaruhi dan menggerakkan orang lain, agar rela dan dapat mengikuti keinginan manajemen demi tercapainya tujuan yang telah ditentukan sebelumnya dengan efisien, efektif dan ekonomis.

Setiap orang yang pernah memimpin satu kesatuan kerja, meskipun kecil pasti menyadari betapa sukarnya menangani persoalan-persoalan kepegawaian. Tingkat kesukaran itu tentunya berlipat ganda dalam suatu organisasi yang besar. Pimpinan organisasi harus mengambil segala langkah yang bersifat preventif maupun regresif, agar supaya berbagai unit di dalam organisasi selalu bekerjasama, jangan sampai bekerja tanpa melihat kaitan kegiatannya dengan unit lain. Sedangkan pimpinan tingkat bawahan bertanggungjawab untuk menjamin bahwa semua perintah dan wewenangnya, ditaati dan dijalankan sepanjang menyangkut pengendalian dan pelaksanaan instruksi atasan.

\section{Pengertian Kinerja}

Istilah kinerja berasal dari kata $J o b$ performence. Setiap organisasi selalu berusaha memacu kinerja pegawainya, sebagai indikator keberhasilan. Kinerja adalah sebuah aksi, bukan kejadian. Aksi itu sendiri terdiri dari banyak komponen dan hasilnya tidak dapat dilihat pada saat itu juga memerlukan waktu tertentu. Pada dasarnya kinerja bersifat individual, karena setiap pegawai memiliki tingkat kemampuan yang berbeda-beda dalam mengerjakan tugasnya, tergantung kombinasi antara kemampuan, usaha dan kesempatan.

Hal ini berarti bahwa kinerja merupakan hasil kerja pegawai dalam bekerja untuk periode waktu tertentu. Oleh sebab itu untuk mencapai kinerja yang tinggi pada suatu organisasi, memerlukan waktu lama dalam membangun integritas, karakteristik dan kemampuan setiap pegawai, sehingga mendapatkan kepercayaan (trust) dari banyak pihak, diperlukan perhatian seksama dari pihak manajemen. Pihak manajemen dapat mengukur kinerja dilihat dari atas unjuk kerja masing-masing pegawai.

\section{Indikator Kinerja}

Ada 5 (lima) indikator untuk mengukur kinerja pegawai secara individu adalah :

\section{Kualitas}

Kualitas kerja diukur dari persepsi karyawan terhadap kualitas pekerjaan yang dihasilkan serta kesempurnaan tugas-tugas terhadap keterampilan dan kemampuan karyawan.

\section{Kuantitas}

Merupakan jumlah yang dihasilkan dinyatakan dalam istilah seperti jumlah unit, jumlah siklus aktivitas yang diselesaikan.

3. Ketepatan waktu

Merupakan tingkat aktivitas diselesaikan pada awal waktu yang dinyatakan, dilihat dari sudut koordinasi dengan hasil output serta memaksimalkan waktu yang tersedia untuk aktivitas lain.

\section{Efektivitas}

Merupakan tingkat penggunaan sumber daya organisasi (tenaga, uang, teknologi, bahan baku) dimaksimalkan dengan maksud menaikkan hasil dari setiap unit dalam penggunaan sumber daya.

5. Kemandirian 
Merupakan tingkat seorang karyawan yang nantinya akan dapat menjalankan fungsi kerjanya Komitmen kerja. Merupakan suatu tingkat dimana karyawan mempunyai komitmen kerja dengan instansi dan tanggung jawab karyawan terhadap kantor (Robbins, 2012).

\section{METODE PENELITIAN}

\section{Objek Penelitian}

Adapun objek dalam penelitian ini adalah FMIPA Universitas Lampung khususnya pada program studi kimia berlokasi di Jln. Prof. Dr. Soemantri Brodjonegoro No.1 Bandar Lampung. Pelaksanaannya pada bulan Mei 2016.

\section{Metode dan Teknik Pengumpulan Data}

Dalam penelitian ini jenis data yang diperlakukan adalah :

a. Data Primer

Data primer merupakan data dasar yang akan diperoleh langsung tanpa perantara orang atau lembaga lain sebagai pihak ketiga. Data primer ini diperoleh dengan wawancara melalui responden dengan menggunakan daftar pertanyaan.

\section{b. Data Sekunder}

Data skunder merupakan data yang diperoleh melalui orang lain yang berhubungan dengan permasalahan yang dipecahkan. Data sekunder ini diperoleh melalui cara studi dokumenter yaitu mengumpulkan dan mempelajari brosurbrosur serta dokumen organisasi.

\section{Sampel dan Populasi}

Menurut Suharsimi Arikunto (2011) apabila subjek penelitian kurang dari 100 orang, maka lebih baik diambil semua untuk dijadikan sampel penelitian, sehingga penelitiannya merupakan penelitian populasi dan apabila jumlah subjek lebih dari 100 orang, maka dapat diambil dengan menggunakan persentase tertentu, yaitu ; $10-15 \%$ atau $20-25 \%$ dari populasi. Berdasarkan pendapat tersebut, maka penulis dalam menentukan pengambilan sampel pada penelitian ini menggunakan teknik sensus sebagian dari keseluruhan elemen atau unsur (populasi) pada Fakultas MIPA Universitas Lampung khususnya Program Studi Kimia berjumlah 35 orang.

\section{Metode Analisis Data}

Untuk pengolahan data dalam bentuk tabulasi hasil jawaban responden kemudian dilakukan analisis data melalui metode analisis secara kualitatif dan analisis kuantitatif.

Analisis kualitatif merupakan analisis yang dinyatakan dalam bentuk uraian dan didasarkan pada data yang telah ada. Data kualitatif merupakan data berupa informasi yang kemudian dikaitkan dengan data lainnya sehingga memunculkan suatu kebenaran.

Analisis kuantitatif yang dilakukan berdasarkan data primer yang diperoleh dari penyebaran instrument (daftar pertanyaan) kepada sampel, dan untuk mengetahui pengaruh dari variabel bebas (independent variable) terhadap variabel terikat (dependent variable).

Persamaan Regresi Linear Sederhana menentukan persamaan regresi linear sederhana untuk $X$ :

$$
Y=a+b X+e
$$

Keterangan:

$\mathrm{Y}=$ Kinerja Pegawai

$\mathrm{a}=$ Konstanta

$\mathrm{b}=$ Koefisien regresi $\mathrm{X}$

$\mathrm{X}=$ Peran Kepemimpinan 
e $=$ Faktor kesalahan

Untuk mengetahui besarnya pengaruh, penghitungan koefisien korelasi tersebut kemudian dilanjutkan dengan Rumus Koefisien Determinasi atau Koefisien Penentu (KP):

$$
K P=(r)^{2} x 100 \%
$$

Untuk menguji secara hipotesis secara parsial digunakan Uji t dengan rumus :

$$
t_{\text {hitung }}=\frac{r \sqrt{N-2}}{\sqrt{1-r^{2}}}
$$

Keterangan:

$$
\begin{array}{ll}
\mathrm{t}_{\text {hitung }} & =\text { Nilai } \mathrm{t} \\
\mathrm{r} & =\text { Koefisien Korelasi } \\
\mathrm{N} & =\text { Jumlah responden }
\end{array}
$$

Kriteria untuk Uji $\mathrm{t}$ adalah sebagai berikut :

a) Jika $t_{\text {hitung }}>t_{\text {tabel }}$ maka Ha diterima dan Ho ditolak.

b) Jika $t_{\text {hitung }} \leq \mathrm{t}_{\text {tabel }}$ maka Ha ditolak dan Ho diterima.

Taraf signifikan dalam penelitian ini digunakan $\alpha=0,05$ atau 5\%. Yang dimaksud dengan Hipotesis nol (Ho) dan Hipotesis alternatif (Ha) adalah :

Ho $=\mathrm{r} \leq 0=$ Berarti tidak ada pengaruh peranan kepemimpinan terhadap kinerja pegawai

$\mathrm{Ha}=\mathrm{r}>0=$ Berarti ada pengaruh peranan kepemimpinan terhadap kinerja pegawai.

\section{HASIL DAN PEMBAHASAN}

\section{Uji Validitas Instrumen}

Pengujian validitas bertujuan untuk mengetahui sejauh mana alat ukur, dalam hal ini kuesioner mengukur apa yang hendak diukur atau sejauhmana alat ukur yang digunakan mengenai sasaran. Jika $r_{\text {hitung }}>r_{\text {tabel }}$, maka butir atau pertanyaan tersebut valid dan jika $r_{\text {hitung }}>r_{\text {tabel }}$, maka butir atau pertanyaan tersebut tidak valid. Hasil uji validitas ditunjukkan pada Tabel 1.

Tabel 1. Hasil pengujian validitas variabel $\mathrm{X}$ dan $\mathrm{Y}$

\begin{tabular}{ccccc}
\hline Variabel & Pertanyaan & $\mathrm{R}$ - hitung & $\begin{array}{c}\mathrm{R} \text { - tabel } \\
\mathrm{N}=35\end{array}$ & Hasil \\
& & & & \\
\hline & 1 & 0,698 & 0,334 & Valid \\
& 2 & 0,646 & 0,334 & Valid \\
Peranan & 3 & 0,582 & 0,334 & Valid \\
Kepemimpinan & 4 & 0,693 & 0,334 & Valid \\
(Variabel X) & 5 & 0,734 & 0,334 & Valid \\
& 6 & 0,634 & 0,334 & Valid \\
& 7 & 0,711 & 0,334 & Valid \\
& 8 & 0,691 & 0,334 & Valid \\
& & & & \\
Kinerja & 1 & 0,624 & 0,334 & Valid \\
Pegawai & 2 & 0,502 & 0,334 & Valid \\
(Variabel Y) & 3 & 0,500 & 0,334 & Valid \\
& 4 & 0,472 & 0,334 & Valid \\
& 5 & 0,500 & 0,334 & Valid \\
& 6 & 0,456 & 0,334 & Valid \\
& 7 & 0,666 & 0,334 & Valid \\
& 8 & 0,624 & 0,334 & Valid \\
\hline
\end{tabular}

Tabel 1. menunjukkan bahwa semua item pertanyaan memiliki koefisien validitas > $\mathrm{r}$ tabel $(0,334)$, dapat diartikan bahwa semua item pertanyaan mengenai peranan kepemimpinan dan kinerja pegawai adalah valid, sehingga dapat digunakan serta mampu menghasilkan data yang akurat sesuai dengan tujuan penelitian.

\section{Uji Reliabilitas Instrumen}

Pengujian reliabilitas dimaksudkan untuk mengetahui kehandalan instrument penelitian kuesioner pada masing-masing variabel, menggunakan $\mathrm{r}$ alpha, hasilnya dapat diketahui setelah dikonsultasikan dengan pedoman interprestasi koefisien penentu (r). Hasil pengujian reliabilitas terhadap item-item kuesioner variabel (X) peranan kepemimpinan adalah 0,646 Alpha Cronbach, nilai ini termasuk dalam koefisien reliabilitas yang tinggi dan hasil pengujian reliabilitas terhadap item-item kuesioner variabel (Y) kinerja pegawai 
adalah 0,699 Alpha Cronbach, nilai ini termasuk dalam koefisien reliabilitas yang tinggi pula. Pedoman instrumen koefisien penentu ditunjukkan pada Tabel 2.

Tabel 2. Pedoman Instrumen Koefisien Penentu

\begin{tabular}{cc}
\hline Interval Koefisien & Kategori \\
\hline $0,00-0,199$ & Sangat Rendah \\
$0,20-0,399$ & Rendah \\
$0,40-0,599$ & Sedang \\
$0,60-0,799$ & Tinggi \\
$0,80-1,000$ & Sangat Tinggi \\
\hline
\end{tabular}

Sumber: Sugiyono (2010).

\section{Analisis Kuantitatif}

Berdasarkan hasil perhitungan persamaan regersi linier sederhana menunjukkan bahwa besarnya korelasi atau pengaruh peranan kepemimpinan terhadap kinerja pegawai ditunjukkan dari nilai $\mathrm{R}$ (corelation), yaitu 0,778 atau $77,8 \%$ dikategorikan tinggi bernilai positif artinya apabila nilai variabel peranan kepemimpinan ditingkatkan maka kinerja pegawai mengalami peningkatan.

Sedangkan nilai koefisien determinasi menunjukkan bahwa (R Square) adalah $78,1 \%$ bernilai positif, artinya kinerja pegawai pada FMIPA Universitas Lampung dipengaruhi secara signifikan peranan kepemimpinan dengan nilai $78,1 \%$, sisanya sisanya $21,9 \%$ dipengaruhi oleh faktor lain yang tidak dibahas dalam penelitian ini.

Berdasarkan hasil perhitungan diperoleh model regresi adalah $\mathrm{Y}=$ $0,702+0,800 X$. Nilai konstanta a memiliki arti bahwa ketika $X$ bernilai 0 , maka $Y$ bernilai 0,702 sedangkan koefisien regresi $b$ memiliki arti bahwa peranan kepemimpinan (X) yang bersifat positif, jika dinaikan peranan kepemimpinan, maka nilai kinerja pegawai (Y) akan meningkat sebesar 0,800.

Berdasarkan hasil pengujian tstudent, menunjukkan bahwa nilai thitung adalah 7,38, sedangkan nilai tabel pada $\mathrm{N}=35$ dan taraf sigifikansi $95 \% \quad(0,05 \%)$ adalah 2,724, maka hasil perbandingannya $t_{\text {hitung }} 7,38>$ $\mathrm{t}_{\text {tabel }} 2,724$, mengandung arti peranan kepemimpinan mempunyai pengaruh yang signifikan terhadap kinerja pegawai pada FMIPA Universitas Lampung.

Hipotesis yang diajukan, yaitu ada pengaruh peranan kepemimpinan terhadap kinerja pegawai pada Fakultas Matematika dan Ilmu Pengetahuan Alam (MIPA) Universitas Lampung, setelah dibuktikan melalui pengujian menggunakan analisis regresi linier sederhana dan uji t hitung, hasilnya menyatakan bahwa pengaruh yang timbul dari peranan kepemimpinan terhadap kinerja pegawai adalah signifikan, artinya pegawai pada FMIPA Universiatas Lampung dipengaruhi peranan kepemimpinan. Dari uraian di atas, maka didapatkan bahwa hipotesis penelitian ada pengaruh peranan kepemimpinan terhadap kinerja pegawai pada Fakultas Matematika dan Ilmu Pengetahuan Alam (MIPA) Universitas Lampung dapat diterima.

\section{KESIMPULAN DAN SARAN}

\section{Kesimpulan}

Dari hasil analisis data dan pembahasan dapat disimpulkan bahwa pengaruh peranan kepemimpinan terhadap kinerja pegawai ditunjukkan dari nilai $\mathrm{R}$ (corelation), yaitu 0,778 atau $77,8 \%$ dikategorikan tinggi bernilai positif artinya apabila nilai variabel peranan kepemimpinan ditingkatkan, maka kinerja pegawai mengalami peningkatan. Peranan kepemimpinan memiliki pengaruh pada kinerja pegawai sebesar $78,1 \%$, sisanya $21,9 \%$ dipengaruhi oleh faktor lain yang tidak dibahas dalam penelitian ini. Hasil pengujian tstudent, menunjukkan bahwa $t_{\text {hitung }} 7,38>t_{\text {tabel }} 2,724$, artinya hipotesis "Ada pengaruh peranan kepemimpinan terhadap kinerja pegawai pada Fakultas Matematika 
dan Ilmu Pengetahuan Alam (MIPA) Universitas Lampung" diterima.

\section{Saran}

Adapun saran yang diberikan pada Fakultas Matematika dan Ilmu Pengetahuan Alam Universitas Lampung adalah:

1. Pimpinan yang baik, selalu ingin mengetahui apakah hasil pelaksanaan pekerjaan yang dilakukan oleh bawahannya sesuai dengan rencana, perintah, tujuan atau kebijaksanaan yang telah ditentukan.

2. Pemimpin hendaknya dapat memberikan motivasi, dorongan melalui peranan sebagai figur untuk berupaya memperbaiki kekurangan dan ketidakseriusan pegawai yang tidak sesuai dengan tugas dan wewenang serta mengatasi kekurangan sarana dan prasarana teori maupun praktek belajar dan mengajar perkuliahan.

\section{DAFTAR PUSTAKA}

Algifari. 2009. Statistik Regresi Linier. Jakarta: LP3ES.

Arikunto, Suharsimi. 2011. Statistik dan Aplikasi. Jakarta: Penerbit Erlangga.

Bernadian. 2013. Manajemen Personalia. Jakarta: LP3ES.

Dharma. 2011. Manajemen Sumber Daya Manusia. Jakarta: Amara Book.

Goal-Path. 2012. Kepemimpinan dan Perilaku Organisasi. Jakarta: Penerbit PT.Raja Grafindo Persada.

Hadi, Sutrisno. 2010. Teori dan Aplikasi Statistik. Yokyakarta: Andi Offset.
Hasibuan, S.P Malayu. 2012. Manajemen Sumber Daya Manusia. Jakarta: Ghalia.

Luthans. 2012. Manajemen Sumber Daya Manusia. Jakarta: PT.Prenhalindo.

Mangkunegara, Prabu Anwar. 2012. Kinerka Kepemimpinan. Jakarta: Bumi Aksara.

Mink. 2013. Manajemen Sumber Daya Manusia. Jakarta: Rineka Cipta.

Nitiseminto, S. Alex. 2012. Manajemen Sumber Daya Manusia dan Manajemen Personalia. Jakarta: PT.Raja Grafindo Persada.

Prawirosentono. 2011. Perilaku Organisasi. Jakarta: Penerbit Prenhallindo.

Robbins. 2012. Manajemen Sumber Daya Manusia. Jakarta: Salemba Empat.

Rusman, Teddy. 2011. Interprestasi Data Statistik. Jakarta: Rineka Cipta.

Sekaran, Uma. 2011. Metodologi Penelitian. Yokyakarta: BPFE UGM.

Siagian, Sondang P. 2010. Manajemen Personalia. Jakarta: Raja Grafindo Persada.

Stoner, James A.F. 2010. Manajemen Personalia. Yokyakarta: Liberty.

Sugiyono. 2010. Metode Penelitian Bisnis. Jakarta: Rineka Cipta.

Syahri, Alhusin. 2010. Program Statistical Product and Service Solution (SPSS) release 17.0. for windows. Jakarta: Gramedia.

Timpe. 2011. Manajemen Sumber Daya Manusia. Yokyakarta: Liberty. 